\title{
Thai-Malay Peninsula and South China Sea networks (500 BC-AD 200), based on a reappraisal of "Sa Huynh-Kalanay"-related ceramics
}

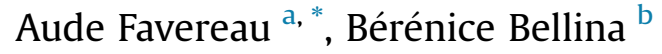 \\ ${ }^{a}$ Muséum National d'Histoire Naturelle (MNHN) - UMR 7194 "Histoire Naturelle de l'Homme Préhistorique", 1 rue René Panhard, 75013 Paris, France \\ ${ }^{\mathrm{b}}$ National Centre for Scientific Research (C.N.R.S) - UMR 7055 “Préhistoire et Technologie”, Maison Archéologie et Ethnologie, 21 allée de l'Université, 92023 \\ Nanterre, France
}

\section{A R T I C L E I N F O}

\section{Article history:}

Available online $\mathrm{xxx}$

\section{Keywords:}

Exchange networks

Thai-Malay Peninsula

Ceramic technology

Iron Age

South China Sea

Southeast Asia

\begin{abstract}
A B S T R A C T
From 500 BC to AD 200, cultural exchanges in the South China Sea were emphasized by the expansion and intensification of long-distance interaction networks. Various archaeological objects, exchanged or imitated, provide evidence of multiple contacts. Interactions in relation to ceramics are attested through the so-called Sa Huynh-Kalanay-related ceramics, whose decorations allow significant stylistic comparisons between sites of the Thai-Malay Peninsula, Vietnam, the Philippines, Borneo and Eastern Indonesia. This paper aims to explore the various modes of circulation of Sa Huynh-Kalanay-related pottery and to define whether they involved the movement of goods and/or of people such as merchants or craftsmen. The analysis focuses on pottery assemblages from fifteen sites recently excavated by the Thai-French archaeological mission in the Thai-Malay Peninsula. The reconstruction of various chaines opératoires and the identification of pottery traditions reveal some Sa Huynh-Kalanay-related pottery were produced by local groups while others have an exogenous origin. Results highlight the socio-cultural and political complexity of groups in line with the production, circulation, and use of the pottery.
\end{abstract}

(c) 2016 Elsevier Ltd and INQUA. All rights reserved.

\section{Introduction}

In mainland Southeast Asia, the period from 500 BC to AD 200 corresponds to deep socio-cultural and political transformations characterized by the emergence of early forms of political centralization and urbanism, as shown at Khao Sam Kaeo in peninsular Thailand (Bellina and Silapanth, 2006; Bellina et al., 2014; Bellina, in press) and Co Loa in northern Vietnam (Kim, 2013). The early historic period, by the beginning of the 1 st millennium $A D$, witnesses the development of cities and states, such as the kingdom of Funan, in southern Vietnam and Cambodia (Stark, 2006; Bourdonneau, 2007; Manguin, 2009). As a corollary to these evolutions, long distance-exchange routes usually named as "Maritime Silk Roads" developed, thus connecting coastal populations surrounding the South China Sea and the Indian Ocean. For the early historical period, and more recently for the late prehistoric period, Southeast Asia exchanges with South Asia and the

\footnotetext{
* Corresponding author.

E-mail addresses: aufavereau@gmail.com (A. Favereau), berenice.bellina@cnrs.fr (B. Bellina).
}

West have been well investigated, especially to document the Indianisation process (to cite only a few recent publications: Bellina, 2007, 2014; Bellina and Glover, 2004; Manguin et al., 2011; Smith, 1999). The external impetus on Southeast Asian cultural evolution has been a matter of intensive debate, which finally ended during the eighties with mixed paradigms conciliating both local creativity and dynamism and external stimulation. However, until recently, very little was known on Maritime Southeast Asian populations' socio-political and economic developments when the region became part of the Maritime Silk roads chain of networks. In the absence of texts, long distance interactions are attested by the growing circulation of valuable goods in the South China Sea networks, characterised by elaborate and exotic technology and styles previously unknown in the region. Those include glass beads and dishes (Lankton et al., 2006; Dussubieux and Gratuze, 2010; Borell, 2012), nephrite and carnelian ornaments (Hung et al., 2006; Bellina, 2007, 2014; Hung and Bellwood, 2010; Hung and Iizuka, 2013; Hung et al., 2013) as well as various metal artefacts such as gold ornaments (Pryce et al., 2008), "Dong Son" bronze drums (Calo, 2009; Pryce et al., 2014), high-tin bronze artefacts (Pryce et al., 2008; Reinecke et al., 2009; Pryce et al., 2014) and Han 
bronze mirrors (Yamagata et al., 2001; Reinecke et al., 2009; Pryce et al., 2008, 2010).

Pottery was also moving throughout the networks. Some arrived from neighbouring regions, South Asia (Bouvet, 2012) and from Han-China (Favereau, 2015; Péronnet et al., forthcoming). In Southeast Asia and the Pacific, it has been thought that regional exchange is indicated by the so-called "Sa Huynh-Kalanay" type of pottery. The expression Sa Huynh-Kalanay was coined by Wilhelm G. Solheim II to express the striking similarities in decorative motifs between Metal Age ceramics from the site of Kalanay in central Philippines and from the site of Sa Huynh in central Vietnam (Solheim, 1964a). The Sa Huynh-Kalanay decorative style is characterized by diagnostic designs, such as scallop designs on carinations and rims, friezes of paired diagonals, sequences of alternating triangles and horizontal "S", interlocking triangles and rectangles, and repeated scrolls or waves (Solheim, 1964b, p. 13). Subsequently, such decorations have been reported elsewhere in Vietnam, the Philippines, peninsular Thailand, Indonesia, Borneo and Cambodia, and the term Sa Huynh-Kalanay was re-used to underline the stylistic link between the various sites (Fig. 1). For Solheim, the Sa Huynh-Kalanay decorated pottery provided at the beginning evidence on the origin and spread of Malayo-Polynesian-speakers groups (Solheim, 1964a, p. 196). Later, it constituted the grounds to explain zones of favoured cultural exchange, the basis of his "Nusantao Maritime Trading and Exchange Network" hypothesis, an alternative to the migration theory developed by Bellwood (1997). Solheim (2006) used it to explain the formation of shared maritime-oriented cultural traits amongst Southeast Asian and Pacific populations, including Austronesian- and nonAustronesian-speakers. To Solheim, shared elements of culture were spread in all directions in the Asia-Pacific region through some sort of trading, and not by migrations, which he thought would have entailed a unidirectional spread (2006, p. 77). Sa Huynh-Kalanay pottery is associated with several major issues of Maritime Southeast Asian and more globally, Asian prehistoric developments. Because these critical issues are at stake, a reappraisal of ceramics bearing this style appears necessary now that some corpora with well dated contexts have recently become available. The Sa Huynh-Kalanay term has limitations, as it has been developed on the basis of morpho-stylistic similarities, which not only overlooks ceramic' diversity but also does not necessarily reflect the reality of interactions.

This research wishes to look beyond the "family resemblance" of these ceramics by investigating their production and distribution networks. What did the exchange consist of? Were the Sa HuynhKalanay decorated potteries really exchanged or imitated? Were potters moving from place to place? In other words, what really circulated: pots, technologies and/or styles? If technologies or styles, who transmitted them? Did they come as part of big or small groups? What were the groups involved in such circulation composed of? What may have been their main activity (trade, craft production ...)? Can we trace their provenance? Finally, can we provide explanations on their production in social terms considering the extended area?

\section{Material and method}

The research presented here focuses on assemblages from the Kra Isthmus in the Thai-Malay Peninsula, as part of a wider reappraisal including comparisons with assemblages from the Philippines, Vietnam and Indonesia (Favereau, 2015). The Kra Isthmus, the upper part of the Thai-Malay Peninsula, corresponds to the westernmost extension of the Sa Huynh-Kalanay ceramic distribution in the South China Sea and where its distribution becomes sparser. Based on the Thai-French Archaeological mission recent dating, the Sa Huynh-Kalanay style appears from c. 500 BC and bears no comparison with earlier assemblages. During this period, the Peninsula was an extremely dynamic region, where local, regional and long distance networks coincided as they traversed transpeninsular routes connecting the Indian Ocean with the South China Sea, or the so-called early Maritime Silk Roads. The material studied comes from fifteen sites recently excavated or surveyed by the Thai-French archaeological mission, including early port settlements and caves used for funerary purposes. They are located either on coastal plains or inland (Fig. 2).

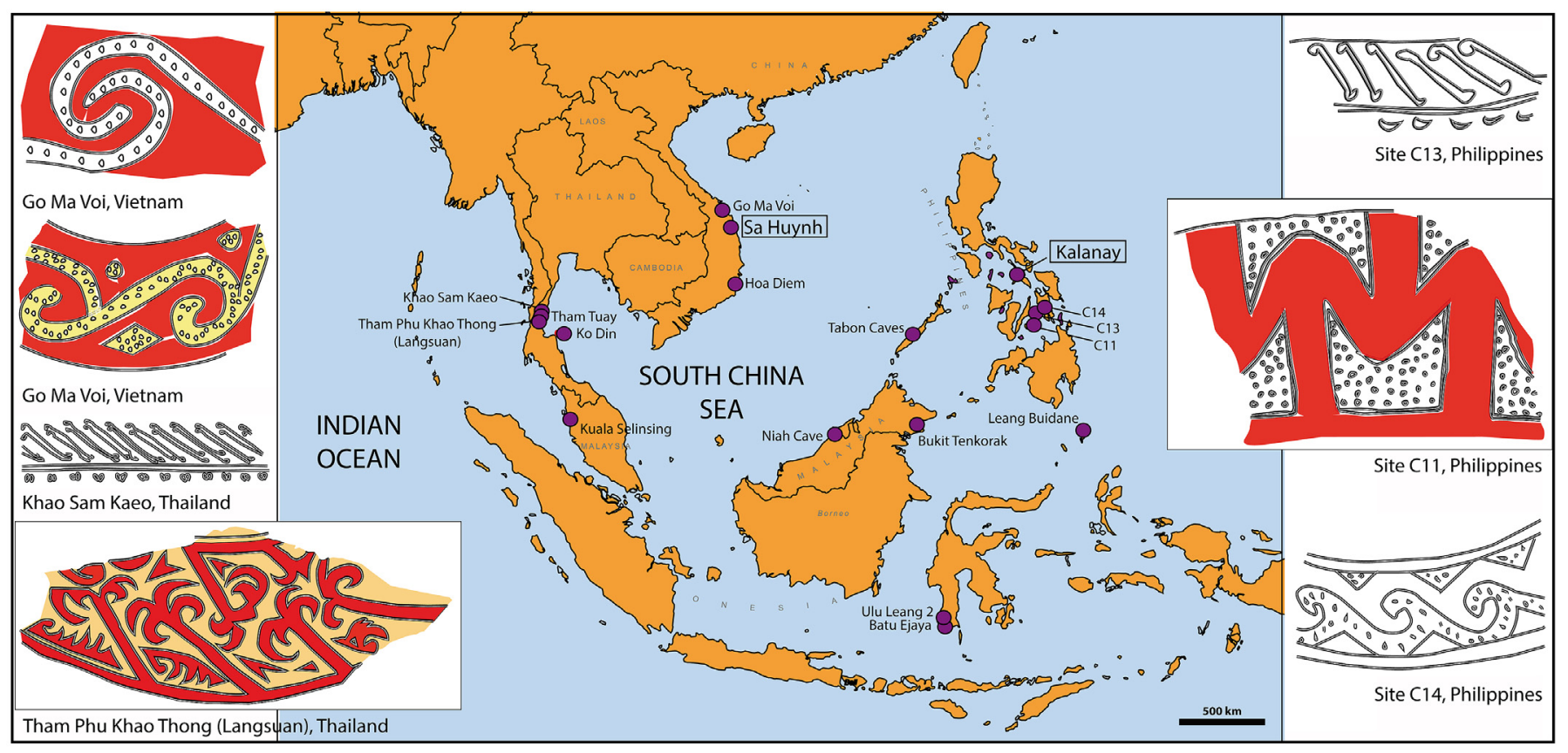

Fig. 1. Map of distribution of some Sa Huynh-Kalanay type potteries in Southeast Asia and examples of typical Sa Huynh-Kalanay-inspired decorations. 


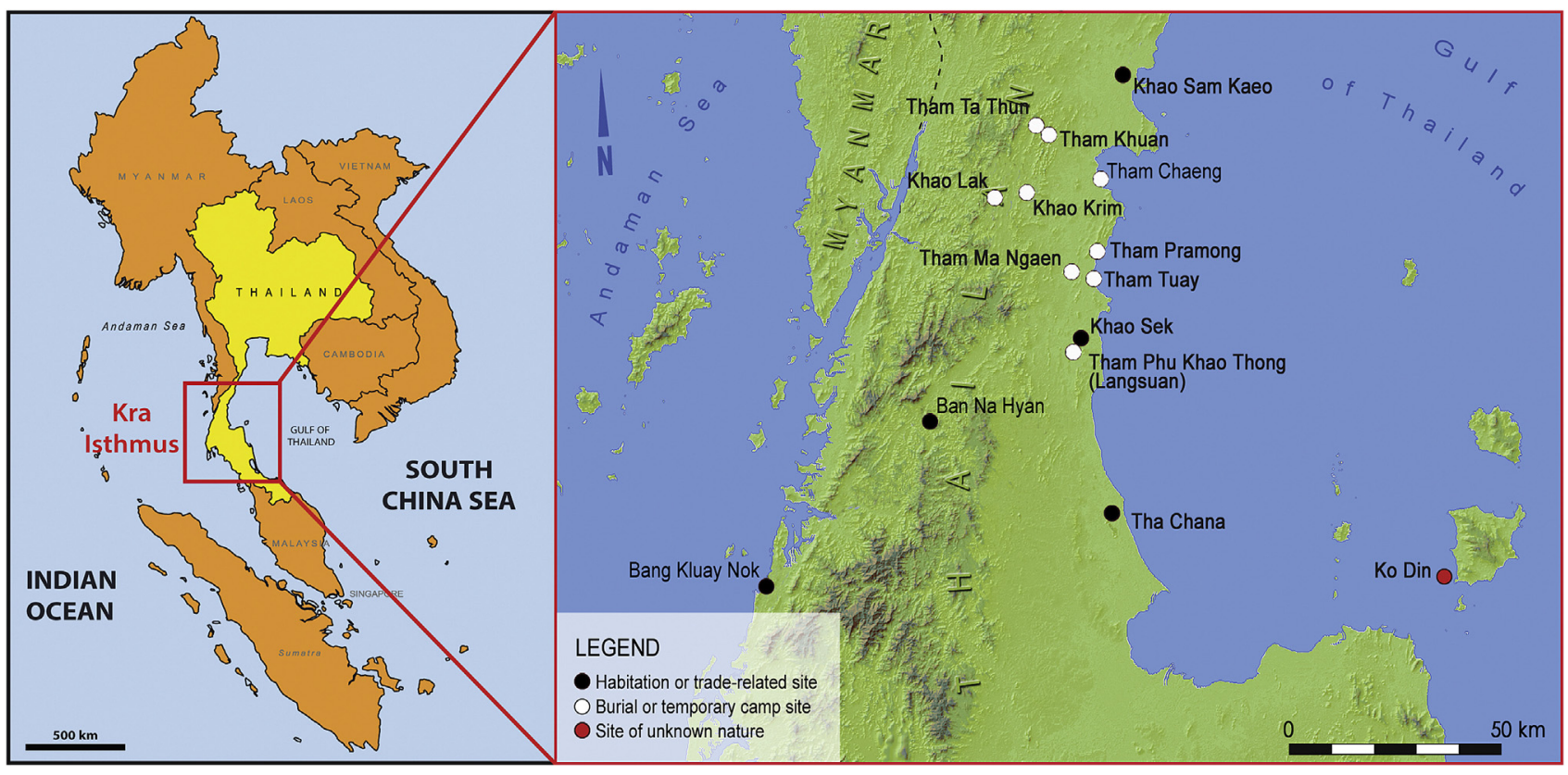

Fig. 2. Location and type of sites under study (Illustration: C. Duval and A. Favereau).

In total, 9391 sherds have been studied (Table 1). Sites are unequally represented. Some, such as Khao Sam Kaeo, Khao Sek, Tham Phu Khao Thong and Tham Tuay were excavated and are well documented (Bellina et al., 2012, 2014). Radiocarbon dates have defined a time range from the 4 th-5th centuries $B C$ to the 1 st century BC. Khao Sam Kaeo, in particular, provided a large amount of sherds previously analysed by Bouvet (2012) and among which we analysed those displaying Sa Huynh-Kalanay-related decorations. Due to intensive looting, other sites only provide a handful of sherds from insecure archaeological contexts. However, thanks to physico-chemical analysis (on glass and metal), technical comparisons (established on stone ornaments and pottery) and morphostylistic parallels (involving stone ornaments, pottery and metal) (Lankton et al., 2006; Pryce et al., 2008; Bellina, 2007, 2014; Bellina et al., 2012; Bouvet, 2012; Pryce et al., 2014), occupations of these sites are estimated between the 4th century BC and the 4th century AD.
The approach used for the analysis was developed by V. Roux and M.A. Courty (Courty and Roux, 1995; Roux and Courty, 2007; Roux, 2010). Based on the concept of the chaine opératoire, it aims to identify techniques used to make a pottery in order to characterize "ways of doing", or "traditions". As shown through ethnoarchaeological studies, ways of doing are culturally inherited and proper to social groups. They are not only typical of the potter but also of the group he belongs to. Through the detailed analysis of macro and micro features created in the ceramic paste during preparation, fashioning, finishing and firing the pot, it becomes possible to reconstruct the chaîne opératoire (Balfet, 1991; Livingstone-Smith, 2007; Roux, 2010). For this, the outer and inner surfaces of each pottery fragment are examined. A sub-sample of thin sections has been conducted in order to provide complementary mineralogical information on the paste and to better observe the orientation of inclusions and voids. Observations are then compared with experimental and ethnoarchaeological databases, allowing us to interpret them in terms of techniques. Finally,

Table 1

Number of sherds studied from fifteen sites in the Thai-Malay Peninsula.

\begin{tabular}{|c|c|c|c|}
\hline Site & Location (district) & Type of site & Number of sherds analysed \\
\hline Tham Phu Khao Thong & Langsuan & Cave site & 2129 \\
\hline Khao Sek & Langsuan & Open air site & 5342 \\
\hline Tham Tuay & Sawi & Cave site & 1437 \\
\hline Khao Sam Kaeo & Mueang Chumphon & Open air site & 183 \\
\hline Tham Chaeng & Sawi & Rockshelter & 60 \\
\hline Tham Ma Ngaen & Sawi & Cave site & 105 \\
\hline Tha Chana & Tha Chana & Open air site & 50 \\
\hline Tham Pramong & Sawi & Cave site & 24 \\
\hline Ko Din & Ko Samui & Unknown & 1 \\
\hline Tham Khuan & Sawi & Cave site & 13 \\
\hline Tham Ta Thun & Sawi & Cave site & 6 \\
\hline Khao Lak & Sawi & Cave site & 3 \\
\hline Khao Krim & Sawi & Cave site & 5 \\
\hline Ban Na Hyan & Phato & Open air site & 30 \\
\hline Bang Kluay Nok & Kapoe & Open air site & 3 \\
\hline Total number of sherds & & & 9391 \\
\hline
\end{tabular}


Table 2

Number of Sa Huynh-Kalanay-related fragments (and MNI) per group.

\begin{tabular}{|c|c|c|c|}
\hline Site & $\begin{array}{l}\text { Group Thai-SHK-Local-1 } \\
\text { Number of sherds (MNI) }\end{array}$ & $\begin{array}{l}\text { Group Thai-SHK-Local-2 } \\
\text { Number of sherds (MNI) }\end{array}$ & $\begin{array}{l}\text { Group Thai-SHK-Exogenous } \\
\text { Number of sherds (MNI) }\end{array}$ \\
\hline Tham Phu Khao Thong & $46(14)$ & $43(15)$ & - \\
\hline Khao Sek & $77(1)$ & - & $370(10)$ \\
\hline Tham Tuay & $9(9)$ & $23(20)$ & $4(4)$ \\
\hline Khao Sam Kaeo & $152(61)$ & $2(2)$ & $8(8)$ \\
\hline Tham Chaeng & - & - & - \\
\hline Tham Ma Ngaen & - & $22(8)$ & - \\
\hline Tha Chana & $8(8)$ & - & $2(2)$ \\
\hline Tham Pramong & $3(2)$ & $21(14)$ & - \\
\hline Ko Din & - & $7(7)$ & $2(2)$ \\
\hline Tham Khuan & $3(3)$ & - & - \\
\hline Tham Ta Thun & $2(1)$ & - & - \\
\hline Khao Lak & $1(1)$ & - & - \\
\hline Khao Krim & $1(1)$ & $2(2)$ & - \\
\hline Ban Na Hyan & - & - & - \\
\hline Bang Kluay Nok & - & - & - \\
\hline Total & $302(101)$ & $120(68)$ & $386(26)$ \\
\hline
\end{tabular}

within the technical groups thus obtained, morphological and stylistic data are considered and interpreted in terms of cultural or functional variations (Roux and Courty, 2007).

\section{Results}

\subsection{Organisation of ceramic production in the Thai-Malay Peninsula}

The reconstruction of pottery chaînes opératoires in the ThaiMalay Peninsula allowed us to distinguish six ceramic traditions. Each tradition is characterized by specific paste, fashioning, finishing and firing techniques. Two of them (Fig. 3) have been interpreted as local, despite the absence of actual production sites, due to their being quantitatively numerous, ubiquitous on the sites where they are identified, and the paste used for their production is coherent with the local geological context.

The most common local tradition (named Thai-Local-1) represents $60.7 \%$ of sherds from all sites examined in the Peninsula. It groups mineral-tempered containers. They are shaped with coils and discontinuous pressures, then scraped. Finished by smoothing, some are burnished. The firing takes place in an oxidizing atmosphere.

The second tradition (named Thai-Local-2) represents $25.7 \%$ of sherds analysed. It includes containers tempered with plant remains. They are shaped using coils and/or slabs, and discontinuous pressures. Surfaces are smoothed and occasionally burnished or slipped. They are fired in a reducing atmosphere.

Both local traditions display various forms of pottery suitable for various domestic uses. Finally, each includes a small amount of pottery decorated with Sa Huynh-Kalanay type of decorations (we refer to these sub-groups hereafter as Thai-SHK-Local-1 and ThaiSHK-Local-2) (Fig. 3). At Khao Sam Kaeo, data obtained by Bouvet (2012) show that the Thai-Local-1 tradition appears predominantly in earlier contexts than Thai-Local-2. Moreover, according to spatial analysis conducted by Malakie Laclair (2008) on the same site, Thai-Local-2 type pottery is mainly concentrated in an area that was occupied by foreign populations (corresponding to hills 3 and 4: see Bellina and Silapanth, 2006, for a detailed description of the configuration of the site). Given these data, we interpreted the Thai-Local-2 tradition as the reflection of a group of migrants who might have been settling in this part of the Thai-Malay Peninsula around $400 \mathrm{BC}$.
The four other traditions identified in the Thai-Malay Peninsula (Fig. 4) have been interpreted as exogenous: they correspond to small amounts of sherds $(0.6-7.9 \%$ of the total number of sherds in the Peninsula) and employ techniques not seen in what are thought to be local traditions. In addition, the pastes, shapes and decorations are proper to each group and not shared with any other group in the area.

The first exogenous tradition (7.9\% of total sherds) is named Thai-Paddled. Containers have a mineral temper and are shaped using the paddle and anvil technique. The outer surface is fully impressed. They are fired in oxidising atmospheres. Although origin of the tradition remains unknown at this stage of the research, containers may be compared with the "Bau-Malay" paddle-impressed pottery first described by Solheim in the Philippines (P. Bellwood, pers. comm.).

The second exogenous tradition (1.6\%), named Thai-SHKExogenous, includes containers with mineral temper, often associated with small fragments of crushed ceramic (grog) or shell. These are shaped with coils or slabs, and discontinuous pressure. The lower halves of pots are paddled. The decorations systematically adopt diagnostic elements of the Sa Huynh-Kalanay style. The firing is oxidized.

The third exogenous tradition (0.6\%) includes Han periodrelated containers (and more likely Western Han period (206 BC-AD 9)), as recognized at Khao Sam Kaeo by Péronnet et al. (forthcoming). Here, ceramics have a fine mineral temper. They are shaped using coils, then discontinuous pressures. In most cases, they are paddled. The inner and outer surfaces are smoothed and the outer surface is covered by paddle impressions and often with stamp impressions. Impressed motifs are typical for pots that were manufactured in China during the Han Dynasty. They are fired in oxidation.

The last exogenous tradition (3.5\%) includes Fine Wares-related pottery (for a detailed study of Fine Wares from Khao Sam Kaeo, see Bouvet, 2012). Containers are comparable with those found on sites from the Indian Ocean basin. The paste is fine, tempered with minerals. They are shaped with the use of rotational kinetic energy, slipped and fired in a reducing atmosphere.

\subsection{Groups using the Sa Huynh-Kalanay style and identified in the Thai-Malay Peninsula}

The study of the various chaines opératoires in the Thai-Malay Peninsula distinguishes three different ways of making containers 


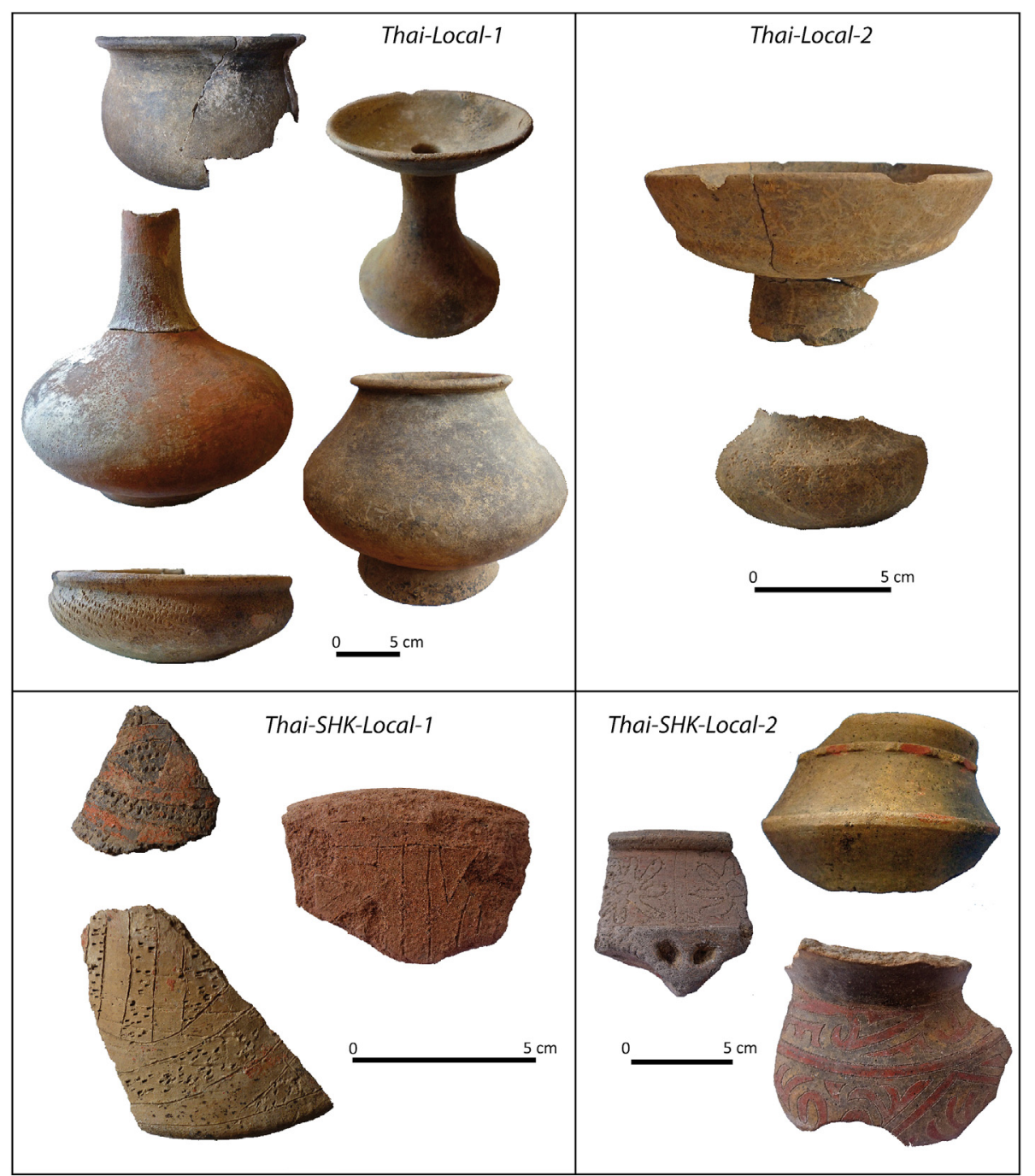

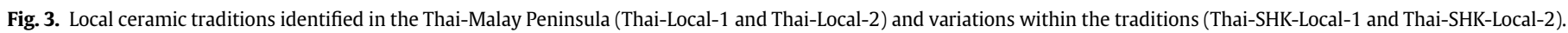

with Sa Huynh-Kalanay decorations. The first two types are produced by local groups (Thai SHK-Local-1 and Thai-SHK-Local-2), and the third is exogenous (Thai SHK-Exogenous) (Fig. 8 and Table 2).

Thai-SHK-Local-1 pottery (Fig. 5) are produced in small quantities $(\mathrm{N}=302$; $\mathrm{MNI}=101)$ and occur in contexts dated from the 5 th to 2 nd century BC. The pots appear on domestic and burial contexts, on ten sites of the Peninsula. The technical signature of the group and the morphologies of containers are local. They correspond to pottery produced by local artisans. Decorations reproduce some typical designs of the Sa Huynh-Kalanay style such as incised horizontal " $S$ " pattern and interlocking triangles. Other motifs evoke the Sa Huynh-Kalanay style but on each site where the group has been identified, decorations are characterized by their own interpretation of the Sa Huynh-Kalanay repertoire.

Thai-SHK-Local-2 (Fig. 6) are reproduced by a group which appear from around $400 \mathrm{BC}$ in the archaeological record. Rare $(\mathrm{N}=120 ; \mathrm{MNI}=68), 95-98 \%$ of containers are found in funerary contexts. They are present on seven sites in the Peninsula and are dated from the 5 th to the 1 st century BC. The technical signature is local. Surfaces are carefully burnished and decorated. Stylistic lexicon mixes diagnostic elements of the Sa Huynh-Kalanay lexicon such as incised spirals, waves or interlocking triangles and patterns impressed with the edge of a shell. Other motives are perfectly originals: indeed, there is no correspondence within the Sa HuynhKalanay lexicon. Lenticular flat surfaces can be found on the periphery of the carina, alternating with small notches. This type of decorations is innovative, since it occurs as early as $400 \mathrm{BC}$, which correspond to the oldest known date for such decorations on Metal Age sites in the South China Sea. On some sites of the Peninsula, pots of this group not only share stylistic similarities but also manufacturing traces are perfectly comparable. Given the scarcity of these pots, this may indicate that the concerned containers have been produced by a single craftsman.

Thai-SHK-Exogenous pottery (Fig. 7) circulated in very small quantities ( $\mathrm{N}=386$; $\mathrm{MNI}=26$ ). The group appears on five sites and is mainly associated with habitation contexts $(80-99 \%$ of the sherds). At Khao Sam Kaeo, sherds occur in contexts dated around the 4 th-2nd century BC on hills 3 and 4 , an area of the site that was likely to be occupied by foreign populations (Bellina and Silapanth, 2008). The chaîne opératoire is totally exogenous. Here, the stylistic lexicon is less varied, mainly displaying strips of paired diagonal incised lines and repeated lenticular flat areas on the carina alternating with impressed notches. 


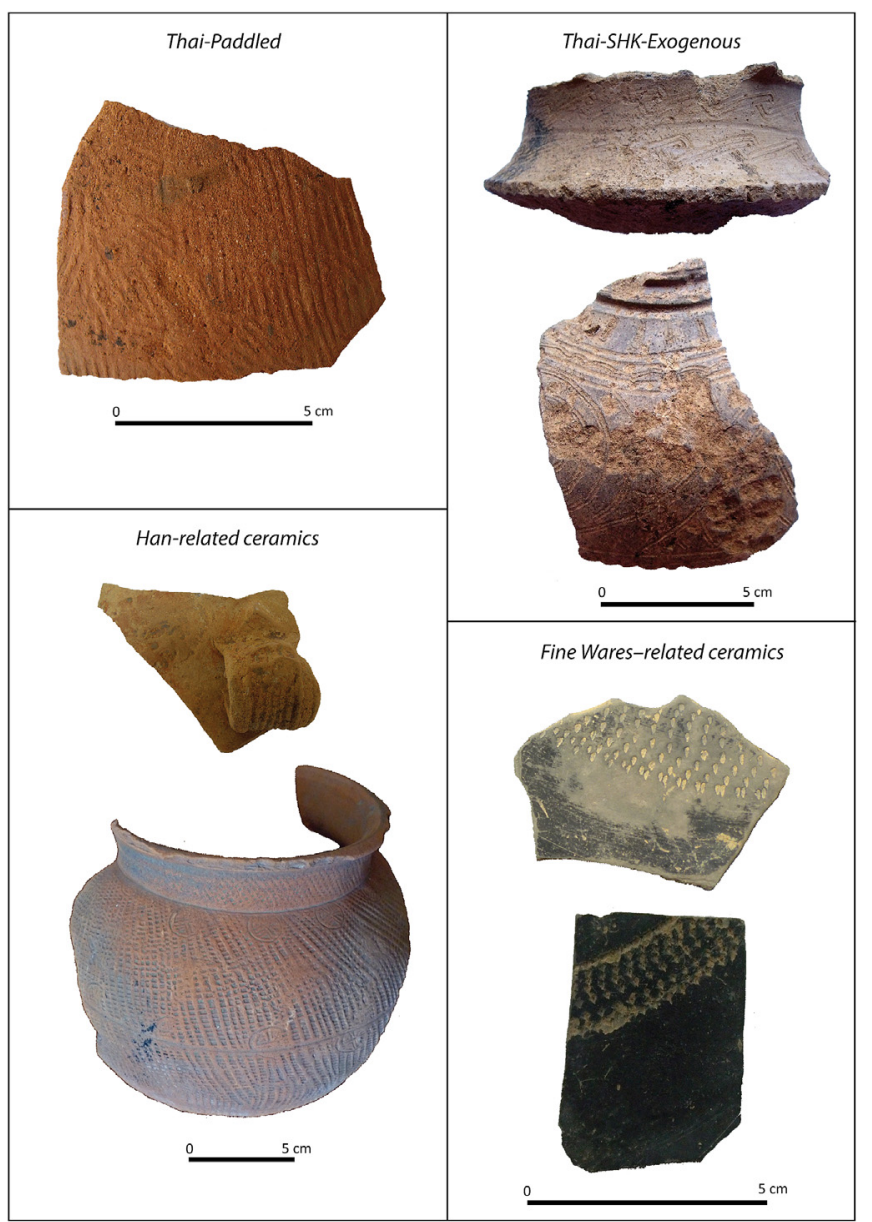

Fig. 4. Exogenous ceramic traditions identified in the Thai-Malay Peninsula (bottom left: Suthi Rattana Foundation).

\section{Discussion and conclusion}

One of the most striking discoveries of this research is the ubiquitous presence, even though in small amounts, of Sa HuynhKalanay style pottery amongst the Upper Peninsula corpus (Fig. 8). Specimens are more numerous in coastal contexts than in inland caves. Of over 15 sites investigated or excavated, 12 yielded

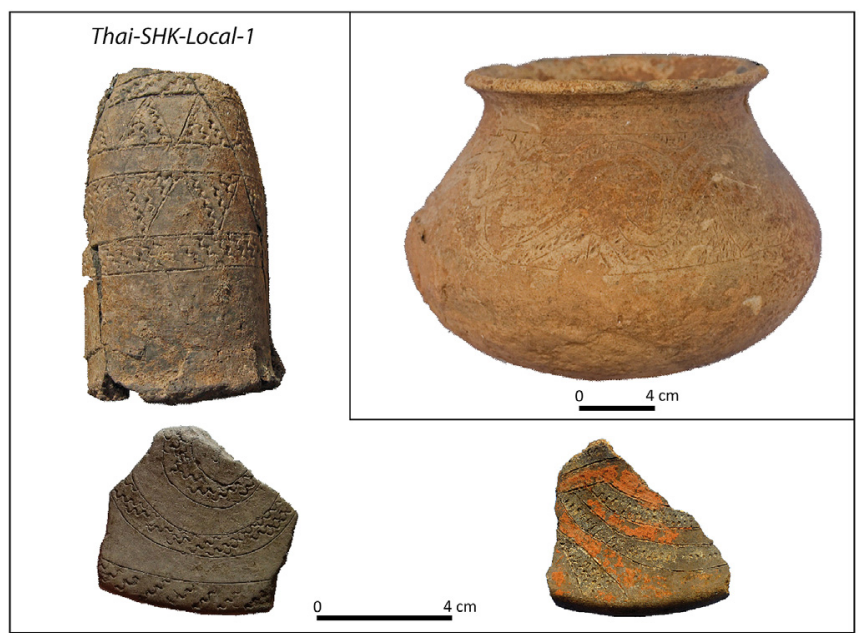

Fig. 5. Locally produced pottery from group Thai-SHK-Local-1.

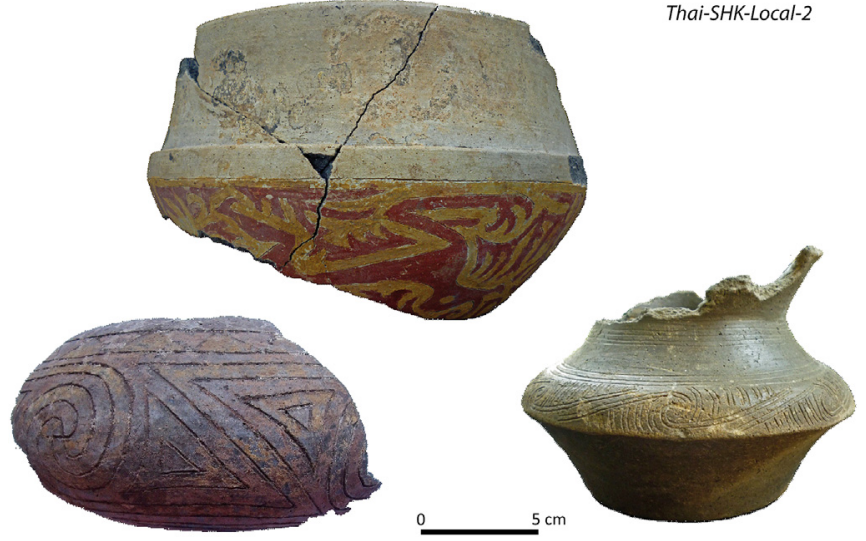

Fig. 6. Locally produced pottery from group Thai-SHK-Local-2 (upper: pottery sherd from Dr. Chawalit Khaokhiew' survey; bottom right: Suthi Rattana Foundation).

Sa Huynh-Kalanay-related corpora, most of which were probably produced by local potters (groups Thai-SHK-Local-1 and Thai-SHKLocal-2).

Thai-SHK-Local-1 corresponds to pottery produced by local potters imitating the Sa Huynh-Kalanay style from 500 BC. There were probably produced on demand for a limited number of individuals. The stylistic diversity from site to site suggests multiple centers of productions. This group raises the question of who group ordered these pots, and for which occasion they wanted to have such containers? Were they local populations willing to copy an exotic style or foreigners present in the Peninsula who would have ordered containers characteristic of their cultural group?

Thai-SHK-Local-2 were produced occasionally by another group of local potters from around $400 \mathrm{BC}$. The great care involved in the containers' making suggests that they may have been produced by craftsmen specialized in high quality productions. Highly similar productions traces and shared stylistic designs might be indicative of a single production center. Given their context of discovery, these potteries may have circulated for special events in relation to funerary rituals.

Thai-SHK-Exogenous is an exogenous group that shows strong stylistic analogies with ceramics from the Kalanay cultural area in the central Philippines but none with Sa Huynh culture typical motifs. However, comparable pottery was unearthed from one site in central Vietnam, Hoa Diem, whose investigators highlighted the

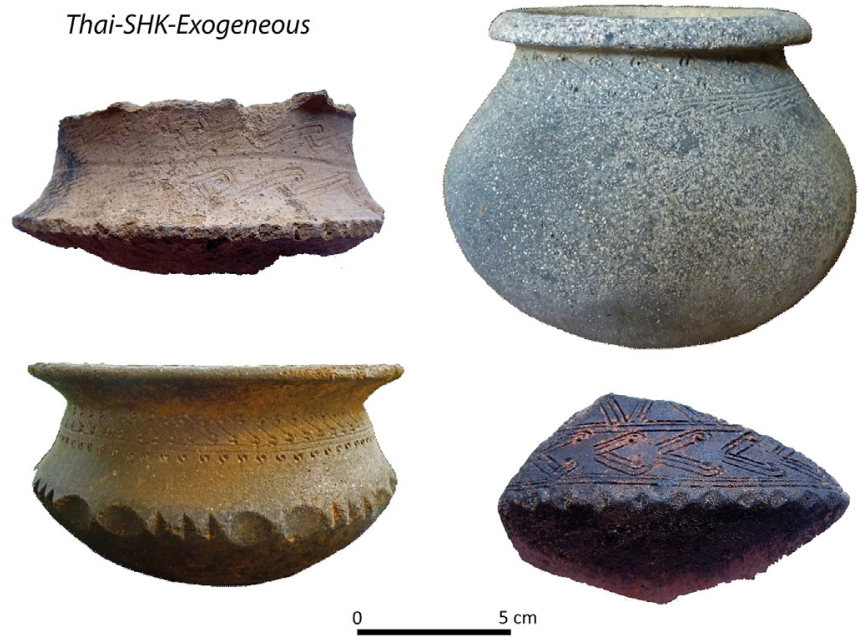

Fig. 7. Exogenous pottery from group Thai-SHK -Exogenous (upper right and bottom left: Suthi Rattana Foundation). 


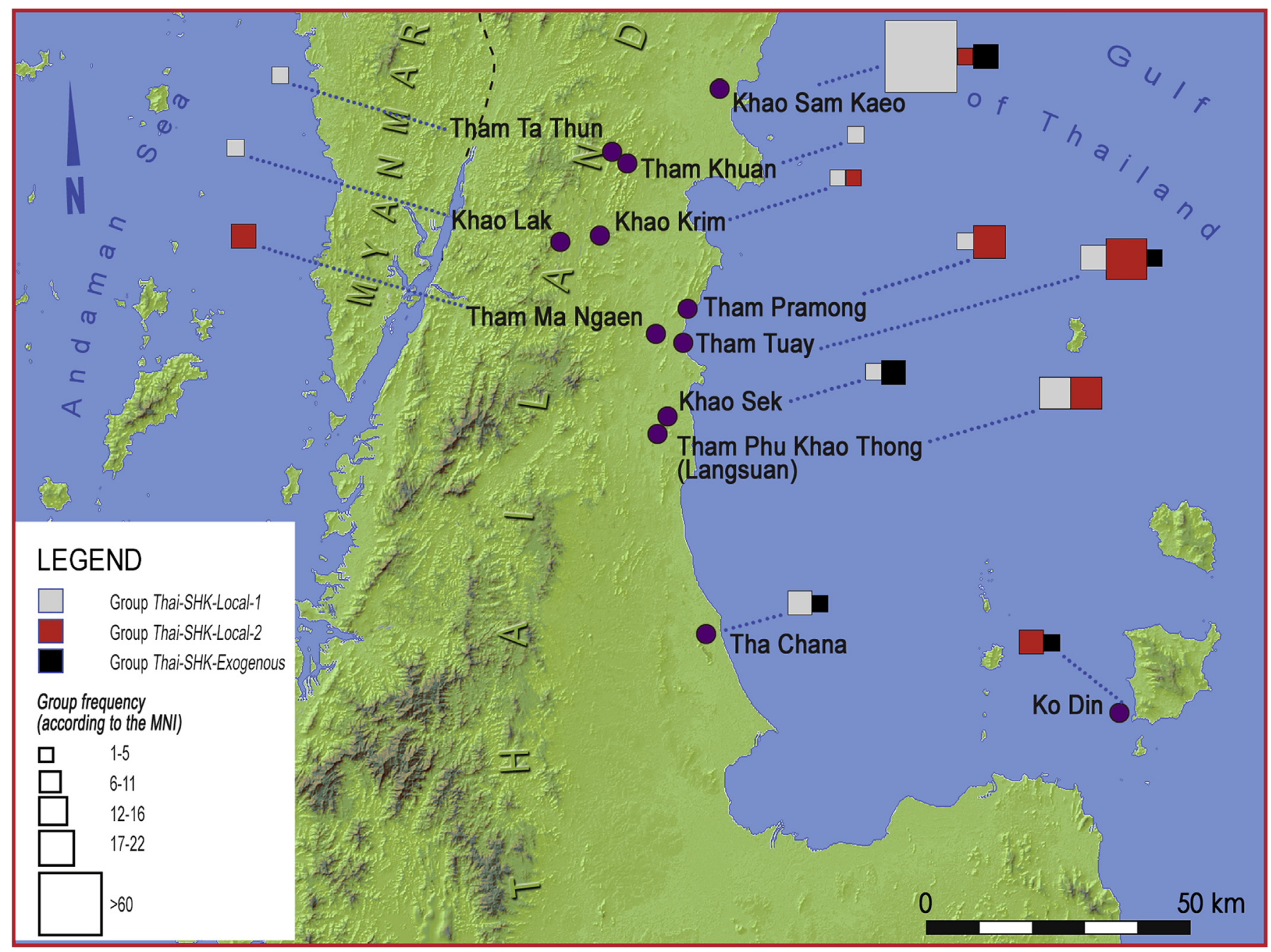

Fig. 8. Distribution of Sa Huynh-Kalanay-related pottery per group in the Thai-Malay Peninsula (Illustration: C. Duval and A. Favereau).

similarities with the site of Kalanay (Yamagata and Hoang, 2008; Yamagata, 2012).

To sum up, in the Thai-Malay Peninsula, Sa Huynh-Kalanayrelated pottery is omnipresent, albeit in very small quantities, and mainly comes from funerary contexts. The technological analysis demonstrated that only a few pots circulated in reality. The majority were produced by local potters to satisfy occasional demand whilst others were imported, probably by a small number of individuals. On the other hand, decorative designs circulated widely. Decorations are likely to play a symbolic role: they are frequently found associated with valuables artefacts such as beads, various ornaments, and metal objects. They may represent a specific form of distinction, proper to small groups of individuals in the Peninsula who were involved at different levels in long-distance exchange. Who were these different groups and what was their role in this complex network involving different ecological niches and socio-political organizations?

Both locally made Sa Huynh-Kalanay ceramics traditions were predominantly found in coastal areas but they occur in inland caves located in the forested zone as well, even if in lesser quantity. However, the assemblage the Thai-French archaeological mission has been able to uncover from inland sites is proportionally much smaller. The first tradition, Thai-Local-1, may represent one group of people and the second, Thai-Local-2, another one who settled in this part of the Peninsula slightly later. The scarcity of data prevents us from formulating a hypothesis on the second group's provenance. This latter group need not have come from far away. Ethnographic accounts describe how some nomadic groups could obtain some manufactured crafts amongst specialists established in coastal trading centers. Further research is needed to check whether a comparable organization may have existed as soon as the late prehistoric period. As for the Thai-SHK-Exogenous, this group traces links with the Philippines and is almost exclusively found within port settlements of cosmopolitan configuration in the Peninsula.

What role each group played in network exchange and in local socio-political developments are amongst future questions this research aims to answer. The complexity of the organisation of the production in this part of the Peninsula from around $500 \mathrm{BC}$ reflects the significant social, political and economic evolution some groups in the South China Sea region - and more specifically the ThaiMalay Peninsula-were facing when the region became a central node of the burgeoning Maritime Silk Roads.

\section{Acknowledgement}

We would like to express our sincere thanks to the Fine Art Department, Silpakorn University (in particular Dr. Rasmi Shoocongdej and Dr. Chawalit Khaokhiew), the National Science 
Museum (in particular Cholawit Thongcharoenchaikit), the Chumphon National Museum and the Suthi Rattana Foundation (in particular Dr. Bunchar Pongpanich), which kindly provided us the opportunities to analyse pottery assemblages from Thailand. We also thank Prof. Mariko Yamagata, Dr. Bui Chi Hoang, Dr. Kim-Dung Nguyen, Dir. Tran Tan Vinh, the Sa Huynh and Cham Culture Museum in Duy Xuyen and the Tam Ky Museum for allowing us to study in Vietnam, as well as Prof. Carla Sinopoli for letting us study the Guthe collection kept in the Museum of Anthropology, Michigan University. We extend our thanks to the Department of Prehistory of the Muséum National d'Histoire Naturelle (UMR 7194) and the PrehSEA project "Managing Prehistoric Heritage in Southeast Asia" for giving us the opportunity to present this research at the XVII World UISSP Congress, and to Prof. Valentine Roux and Dr. Thomas Oliver Pryce (UMR 7055) for valuable advice. Special thanks to Carole Duval (UMR 7055) for her work on illustrations. The Thai-French archaeological mission has received financial support from the French Ministry of Foreign Affairs (and its excavation division) and the National Centre for Scientific Research (CNRS). Part of the results in this article are presented in A. Favereau PhD thesis (advisors: Dr. C. Comentale, Prof. V. Roux and Dr. B. Bellina) that was funded by the Region Ile-de-France and conducted at the Department of Prehistory of the Muséum National d'Histoire Naturelle (UMR 7194).

\section{References}

Balfet, H. (Ed.), 1991. Observer l'action technique: des chaî̀nes opératoires, pour quoi faire?. CNRS, Paris, France.

Bellina, B., 2007. Cultural Exchange between India and Southeast Asia: Production and Distribution of Hard Stone Ornaments, VIc BC-VIc AD. Maison des sciences de l'homme, Paris, France.

Bellina, B., 2014. Maritime Silk Roads' ornament industries: socio-political practices and cultural transfers in the South China Sea. Cambridge Archaeological Journal 24, 345-377.

Bellina, B., in press. Was there a late prehistoric integrated Southeast Asian maritime space? Insight from settlements and industries. In: Acri, A., Landmann, A. (Eds.), Cultural Transfers in Historical Maritime Asia: Austronesian-Indic Encounters. Q5 Institute of South-East Asian Studies, Singapore.

Bellina, B., Epinal, G., Favereau, A., 2012. Caractérisation préliminaire des poteries marqueurs d'échanges en mer de Chine méridionale à la fin de la préhistoire. Archipel 7-33.

Bellina, B., Glover, I.C., 2004. The archaeology of early contacts with India and the Mediterranean World from the fourth century BC to the fourth century AD. In: Glover, I.C., Bellwood, P. (Eds.), Southeast Asia, from the Prehistory to History. Routledge/Curzon Press, London, pp. 68-89.

Bellina, B., Silapanth, P., 2006. Khao Sam Kaeo and the Upper Thai Peninsula: understanding the mechanisms of early trans-asiatic trade and cultural exchange. In: Bacus, E.A., Glover, I.C., Pigott, V.C. (Eds.), Uncovering Southeast Asia's Past: Selected Papers from the 10th International Conference of the European Association of Southeast Asian Archaeologists. National University of Singapore Press, Singapore, pp. 379-392.

Bellina, B., Silapanth, P., 2008. Weaving cultural identities on trans-Asiatic networks: upper Thai-Malay Peninsula - an early socio-political landscape. Bulletin de l'École française d'Extrême-Orient 93, 257-293.

Bellina, B., Silapanth, P., Chaisuwan, B., Thongcharoenchaikit, C., Allen, J., Bernard, V., Borell, B., Bouvet, P., Castillo, C., Dussubieux, L., Malakie Laclair, J., Srikanlaya, S., Péronnet, S., Pryce, T.O., 2014. The development of coastal polities in the Upper Thai-Malay Peninsula. In: Revire, N., Murphy, S.A. (Eds.), Before Siam was Born: New Insights on the Art and Archaeology of Pre-Modern Thailand and its Neighbouring Regions. River Books, Bangkok, Thailand, pp. 68-89.

Bellwood, P., 1997. Prehistory of the Indo-Malaysian Archipelago. University of Hawaii Press, Honolulu, Etats-Unis.

Borell, B., 2012. The Han period glass dish from Lao Cai, Northern Vietnam. Bulletin of the Indo-Pacific Prehistory Association 32, 70-77.

Bourdonneau, E., 2007. Réhabiliter le Funan, Óc Eo ou la première Angkor. Bulletin de l'Ecole française d'Extrême-Orient 94, 111-158.

Bouvet, P., 2012. Interactions culturelles entre l'Asie du Sud-Est et l'Inde aux 4è-2è s. av. J.-C.: étude technologique des céramiques de Khao Sam Kaeo (Thaïlande péninsulaire, province de Chumphon) (PhD thesis). University Paris-OuestNanterre-La Défense, France.

Calo, A., 2009. The Distribution of Bronze Drums in Early Southeast Asia: Trade Routes and Cultural Sphere. Archaeopress, Oxford, Royaume-Uni.
Courty, M.-A., Roux, V., 1995. Identification of wheel throwing on the basis of ceramic surface features and microfabrics. Journal of Archaeological Science 22, $17-50$.

Dussubieux, L., Gratuze, B., 2010. Glass in Southeast Asia. In: Bacus, E.A., Bellina, B. Pryce, T.O., Wisseman Christie, J. (Eds.), 50 Years of Archaeology in Southeast Asia: Essays in Honour of Ian Glover. River Books, Bangkok, Thailand, pp. 244-257.

Favereau, A., 2015. Interactions et modalités des échanges en Mer de Chine méridionale (500 avant notre ère - 200 de notre ère): approche technologique des assemblages céramiques ( $\mathrm{PhD}$ thesis). Muséum National d'Histoire Naturelle, Paris, France.

Hung, H., Bellwood, P., 2010. Movement of raw materials and manufactured goods across the South China Sea after 500 BCE: from Taiwan to Thailand, and back. In: Bellina, B., Bacus, E.A., Pryce, T.O., Wisseman Christie, J. (Eds.), 50 Years of Archaeology in Southeast Asia: Essays in Honour of Ian Glover. River Books Bangkok, Thailand, pp. 235-245.

Hung, H., Iizuka, Y., 2013. The Batanes nephrite artefacts. In: Bellwood, P., Dizon, E. (Eds.), 4000 Years of Migration and Cultural Exchange: the Archaeology of the Batanes Islands, Northern Philippines, Terra Australis 40. Australian National University Press, pp. 149-168.

Hung, H., Iizuka, Y., Bellwood, P., 2006. Taiwan jade in the context of Southeast Asian archaeology. In: Bacus, E.A., Glover, I.C., Pigott, V.C. (Eds.), Uncovering Southeast Asia's Past: Selected Papers from the 10th International Conference of the European Association of Southeast Asian Archaeologists. National University of Singapore Press, Singapore.

Hung, H., Nguyen, K.D., Bellwood, P., Carson, M.T., 2013. Coastal connectivity: long term trading networks across the South China Sea. Journal of Island and Coastal Archaeology 8, 384-404.

Kim, N.C., 2013. Lasting monuments and durable institutions: labor, urbanism, and statehood in Northern Vietnam and beyond. Journal of Archaeological Research 21, 217-267.

Lankton, J.W., Dussubieux, L., Gratuze, B., 2006. Glass from Khao Sam Kaeo: transferred technology for an early Southeast Asian exchange network. Bulletin de l'École française d'Extrême-Orient 93, 317-351.

Livingstone-Smith, A., 2007. Chaîne opératoire de la poterie: références ethnographiques, analyses et reconstitution. Musée royal de l'Afrique centrale, Tervuren, Belgium.

Malakie Laclair, J., 2008. Identifying Patterns between the Looting Pits: Spatial Analysis at Khao Sam Kaeo (MSc Dissertation in GIS and Spatial Analysis in Archaeology). University of London.

Manguin, P.-Y., 2009. The archaeology of Funan in the Mekong River Delta: the Oc Eo culture of Vietnam. In: Tingley, N. (Ed.), Arts of Ancient Vietnam: from River Plain to Open Sea: Asia Society, Museum of Fine Arts. Yale University Press, New York, Houston, pp. 100-118.

Manguin, P.-Y., Mani, A., Wade, G. (Eds.), 2011. Early Interactions between South and Southeast Asia: Reflections on Cross-cultural Exchange. Institute of Southeast Asian Studies, Singapore.

Péronnet S., Srikanlaya, S., Bellina, B., in press. Khao Sam Kaeo, the Han-related ceramics. In: Bellina, B. (Ed.), Khao Sam Kaeo, an Early Industrial Port City between the Indian Ocean and the South China Sea. Ecole Française D'Extrême Orient, Paris, France.

Pryce, T.O., Baron, S., Bellina, B., Bellwood, P., Chang, N., Chattopadhyay, P., Dizon, E. Glover, I.C., Hamilton, E., Higham, C., Kyaw, A.A., Laychour, V., Natapintu, S., Nguyen, V., Pautreau, J.P., Pernicka, E., Pigott, V.C., Pollard, M., Pottier, C. Reinecke, A., Sayavongkhamdy, T., Souksavatdy, V., White, J., 2014. More questions than answers: the southeast Asian Lead Isotope project 2009-2012. Journal of Archaeological Science 42, 273-294.

Pryce, T.O., Bellina, B., Bennett, A., 2008. The development of metal technologies in the Upper Thai-Malay Peninsula: initial interpretation of the archaeometallurgical evidence from Khao Sam Kaeo. Bulletin de l'École française d'Extrême-Orient 93, 295-315.

Pryce, T.O., Pigott, V.C., Martinón-Torres, M., Rehren, T., 2010. Prehistoric copper production and technological reproduction in the Khao Wong Prachan Valley of Central Thailand. Archaeological and Anthropological Sciences 2, 237-264.

Reinecke, A., Vin, L., Seng, S., 2009. The First Golden Age of Cambodia: Excavation at Prohear. Deutschen Archäologischen Instituts, Bonn, Germany.

Roux, V., 2010. Lecture anthropologique des assemblages céramiques. Fondements et mise en oeuvre de l'analyse technologique. In: Les nouvelles de l'archéologie. vol. 119, pp. 4-9.

Roux, V., Courty, M.A., 2007. Analyse techno-pétrographique céramique et interprétation fonctionnelle des sites: un exemple d'application dans le Levant Sud chalcolithique. In: Bain, A., Chabot, J., Moussette, M. (Eds.), La mesure du passé: contributions à la recherche en archéométrie (2000-2006). Archaeopress, Québec, Canada, pp. 153-168.

Smith, M.L., 1999. 'Indianization' from the Indian point of view: trade and cultural contacts with Southeast Asia in the early first millennium C.E. Journal of the Economic and Social History of the Orient 42, 1-26.

Solheim, W.G., 1964a. Further relationships of the Sa-Huýnh-Kalanay pottery tradition. Asian Perspectives 8, 196-211.

Solheim, W.G., 1964b. The Archaeology of Central Philippines: a Study Chiefly on the Iron Age and its Relationships. In: Monographs of the National Institute of Science and Technology, vol. 10. Bureau of Printing, Manila, Philippines.

Solheim, W.G., 2006. Archaeology and Culture in Southeast Asia: Unraveling the Nusantao. University of the Philippines Press, Diliman, Quezon City, Philippines. 
Stark, M.T., 2006. Pre-Angkorian settlement trends in Cambodia's Mekong Delta and the Lower Mekong Archaeological Project. Bulletin of the Indo-Pacific Prehistory Association 26, 98-109.

Yamagata, M., 2012. The Excavation of Hoa Diem in Central Vietnam. In: Showa Women's University Institute of International Culture Bulletin, vol. 17. Showa Women's University Institute, Tokyo.
Yamagata, M., Hoang, Bui Chi, 2008. Archaeological Research on the Prehistoric Interrelations beyond the South China Sea. Report n ${ }^{\circ} 18520593$ of Grant-in-Aid for Scientific Research. Institute of Social Sciences in Vietnam, Waseda University, Tokyo.

Yamagata, M., Pham, D.M., Hoang, Bui Chi, 2001. Western Han Bronze mirrors recently discovered in central and Southern Vietnam. Bulletin of the IndoPacific Prehistory Association 21, 99-106. 